Article

\title{
The Influence of Emulsified Water Fuel Containing Fresh Water Microalgae on Diesel Engine Performance, Combustion, Vibration and Emission
}

\author{
Saddam H. Al-lwayzy ${ }^{1,2, *}$, Talal Yusaf ${ }^{1,3}$, Khalid Saleh ${ }^{1}$ and Belal Yousif ${ }^{1}$ \\ 1 School of Mechanical and Electrical Engineering, Faculty of Health, Engineering and Sciences (HES), \\ University of Southern Queensland, Toowoomba, QLD 4350, Australia \\ 2 Department of Agricultural Machinery, College of Agriculture and Forestry, University of Mosul, \\ Al-Majmoa'a Street, Mosul 09334, Iraq \\ 3 Pro-Vice Chancellor Office, Federation University Australia, Mount Helen, VIC 3350, Australia \\ * Correspondence: allwayzs@usq.edu.au; Tel.: +61-746-311-901
}

Received: 12 April 2019; Accepted: 25 June 2019; Published: 2 July 2019

check for updates

\begin{abstract}
Microalgae is considered as an excellent potential renewable source of fuel in many forms including powder or slurry. A high percentage of emulsified water in the fuel is reported to reduce diesel engines' emissions such as $\mathrm{NO}_{\mathrm{x}}$, but that will compromise the engine output power. Using microalgae powder as an additive to enhance the emulsified water fuel heating value is the main objective of this work. Diesel engine combustion, vibration, performance and emissions were evaluated for pure cottonseed biodiesel (CS-B100), emulsified water 20\% (vol.) in cottonseed biodiesel (CSB-E20) and emulsified water 20\% (vol.) containing Fresh Water Microalgae Chlorella Vulgaris (FWM-CV) in cottonseed biodiesel (CSB-ME20). The emulsified water fuels showed a reduction in in-cylinder pressure, vibration, brake power, torque, exhaust gas temperature, $\mathrm{CO}_{2}$ and $\mathrm{NO}_{\mathrm{x}}$, while BSFC and $\mathrm{O}_{2}$ were higher than the pure biodiesel (CS-B100). CSB-ME20 produced higher power and torque than CSB-E20 due to the presence of microalgae in the fuel that increased the energy content of the fuel.
\end{abstract}

Keywords: emulsified water fuel; microalgae biodiesel; engine performance; combustion and vibration; exhaust gas emissions

\section{Introduction}

The current strict regulations on global environmental protection to reduce the exhaust gas emissions produced from diesel engines has attracted the attention of governments, industry and researchers [1-3]. The main adopted strategies to enhance combustion and reduce the emissions are by developing alternative fuels, additives to the current fuels and post treatment of the engine product [4]. Liquids biofuels can be used as fuels or additives to run diesel engines, and they are compatible with the current fuel storage and distribution systems. Biodiesel is a renewable and environmentally-friendly alternative fuel for diesel engines [5]. Biodiesel fuel emits less harmful exhaust gas emissions [6-8]. However, in most cases [9-11], the $\mathrm{NO}_{\mathrm{x}}$ emission was reported to be higher than petroleum diesel (PD) because of the high $\mathrm{O}_{2}$ content in biodiesel. Adding water to biodiesel fuel was an effective method for reducing $\mathrm{NO}_{\mathrm{x}}$ associated with biodiesel [12-14].

Emulsified water in diesel or biodiesel is regarded as a potential fuel in terms of its renewability, emission reduction, economy and adaptability with the current technology. The addition of water to the available fuels provides the key solution to the problem of increasing fuel demands and high fuel prices $[6,7,14-17]$. Emulsion fuel is a term usually used to describe mixtures of diesel and/or biodiesel 
with water [7]. Diesel engines can be fuelled with water-diesel or biodiesel emulsions with minor or no engine modification $[6,7,15,18]$.

Owing to the differences in the physical and chemical properties of the mixture components (i.e., water, diesel or biodiesel), chemical emulsifiers are normally used to facilitate the interaction between the mixture components and prolong the stability of the emulsion. It has been reported that emulsified water in diesel or biodiesel enhances the combustion efficiency $[7,19,20]$. According to Fayyad et al. [21], emulsion fuels were first brought to attention in 1931 by Joseph Vance, and the fuels are still not very well known or accepted by consumers. The use of emulsified water in diesel or biodiesel fuels has been widely investigated by many researchers [14,15,18,19,22]. NadeemRangkuti [15] had evaluated the factors affecting the preparation of emulsified water in diesel and their impact on engine performance and emission. FahdWenming [18] performed an experimental test using a four-cylinder 2.5-L direct injection turbocharged diesel engine to study the effect of using 10\% emulsified water (DE10) on engine performance and emission at different engine loads. The main finding was a reduction in the engine power with DE10 and a concurrent increase in BSFC. An engine test was carried out by Basha and Anand [16] on a diesel engine fuelled with emulsion fuel of $83 \%$ jatropha biodiesel with alumina nanoparticles, $15 \%$ water and $2 \%$ emulsifier. Grimes et al. [23] limited the increase in $\mathrm{NO}_{\mathrm{x}}$ emission from a B20 biodiesel blend using 6.5\% emulsified water in B20. Similarly, a significant reduction of $\mathrm{NO}_{\mathrm{x}}$ (from 1100 to $400 \mathrm{ppm}$ ) was observed by Dantas Neto et al. [24] when using biodiesel with $30 \%$ emulsified water, and the BSFC was close to that achieved with PD [25]. OgunkoyaLi [14] and Koc and Abdullah [26] studied both diesel engine performance and emissions when fuelled with biodiesel blends with and without emulsified water. They concluded that the BSFC and CO level were higher with emulsion fuel than with biodiesel blends. The outcomes and the conclusions of the aforementioned studies differed widely. This could be attributed to many factors such as the procedure followed in preparing the emulsions, differences in the chemical and physical properties of emulsion constituents, variation in blend ratios, differences in specification, the age of the engines used in the tests, and environmental conditions in the laboratories.

It is noteworthy that the results of the literature showed diverse findings on the engine power, $\mathrm{CO}$ emission and $\mathrm{NO}_{\mathrm{x}}$ emission [22]. The majority of the researchers reported a reduction in brake power produced by the engine utilising emulsion fuel compared with diesel due to the presence of water that reduced the total energy content of the emulsion mixture. However, Abu-Zaid [19] and FayyadAbu-Ein [21] reported an increase in power achieved by using emulsified water fuel. OgunkoyaLi [14] reported that the results of emissions from water emulsion fuel varied based on the engine specification and test condition. Most of the studies of the effect of the water emulsion fuel in diesel engine were performed at limited operating conditions [27]; therefore, further experimental studies are required for a comprehensive understanding of emulsion fuel at a variety of engine speeds and loads [14], and increasing the energy content of the emulsion fuel is essential to maintain the required engine power.

Engine vibration performance is an important factor that needs to be considered with any proposed alternative fuel for a diesel engine, and only few researchers have tested and reported the alternative fuel effect on engine vibration. As an example, an experimental work was conducted to study the noise and vibration characteristics of diesel engine fuelled with sunflower, canola, and corn biodiesel blends at different percentages of volume ratio and $\mathrm{H}_{2}$ injected through the inlet manifold at different flow rates [28]. UludamarYıldızhan [28] found that biodiesel blends reduce the vibration of the engine block. On the other hand, Taghizadeh-Alisaraei et al. [29] measured the vibration using different blends of diesel and biodiesel fuels (canola and soybean, animal fats, waste oil). It was found that fuel blends significantly influence the vibration, and the vibration of the diesel was less than pure biodiesel fuel, while the vibration increased with the increase of the biodiesel ratio from 15 up to 50\% [29].

The literature review shows that the research on the diesel engine vibration and performance due to using the emulsified water in the biodiesel fuel and adding additives to enhance its energy content 
has not been reported so far. Therefore, this study was conducted to study the effect of these additions on combustion, vibration and emission of a single-cylinder diesel engine.

\section{Materials and Methods}

\subsection{Fuel Preparation}

To study the engine combustion characteristics, vibration, performance and exhaust gas emissions of emulsified water in biodiesel with and without microalgae as an additive, three fuels were prepared. Cottonseed biodiesel 100\% (CS-B100) was used as the base reference in the engine test and to form emulsified fuels. The second fuel was $20 \%$ emulsified water in cottonseed biodiesel (CSB-E20). The third fuel was $20 \%$ emulsified water containing microalgae in cottonseed biodiesel (CSB-ME20). The CSB-E20 and CSB-ME20 fuel were prepared using an ultrasonic horn reactor as the mixing method. The cottonseed biodiesel of about $79.2 \%$ volumetric percentage was mixed with $19.8 \%$ water and $1 \%$ emulsifier (Triton X-100) to form a homogenised emulsion. For the CSB-ME20, the water containing microalgae were also treated with ultrasound (before it was mixed with cottonseed biodiesel) to break down the size of the microalgae colonies (which had a size larger than the nozzle orifice) into individual cells to prevent injector blockage; see Figure 1.
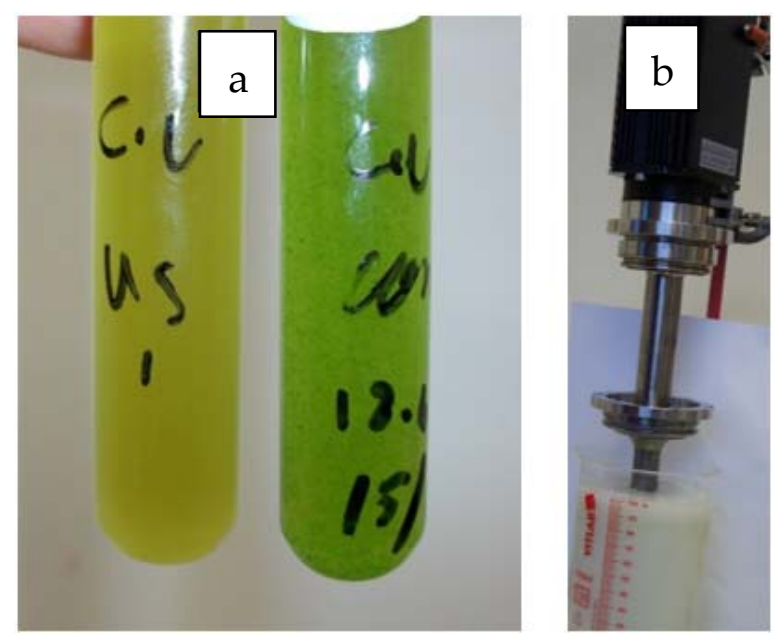

Figure 1. Samples of water containing FWM-CV (a), left sample treated with ultrasound, right sample un-treated. (b) Emulsified water in biodiesel and the ultrasound device.

The effect of the surfactant on the fuel was neglected as it was $1 \%$ of the total emulsion fuels' volume and was used in both CSB-E20 and CSB-ME20. The detailed description of growing FWM-CV and emulsion fuels' preparation were presented in [30]. The measured fuels' properties are given in Table 1 . The dynamic viscosity of the emulsion fuels was increased significantly compared to the pure biodiesel. This increase was due to the change of the structure of the emulsified fuel and the presence of water, which might form saponification.

Table 1. Measured physical fuel properties Reproduced from [30], MDPI: 2014.

\begin{tabular}{|c|c|c|c|c|}
\hline Fuel Type & $\begin{array}{l}\text { Density }\left(\mathrm{kg} \cdot \mathrm{L}^{-1}\right) \\
\left(@ 20^{\circ} \mathrm{C}\right)\end{array}$ & $\begin{array}{c}\text { Dynamic Viscosity } \\
(\mathrm{cP})\left(@ 25{ }^{\circ} \mathrm{C}\right)\end{array}$ & $\begin{array}{l}\text { Surface Tension } \\
\quad\left(\mathrm{mN} \cdot \mathrm{m}^{-1}\right)\end{array}$ & $\begin{array}{c}\text { Heat of Combustion } \\
\left(\mathrm{MJ} \cdot \mathrm{kg}^{-1}\right)\end{array}$ \\
\hline CS-B100 & $0.898 \pm 0.015$ & 8.2 & $28.54 @ 28.8^{\circ} \mathrm{C}$ & 39.3 \\
\hline CSB-E20 & $0.908 \pm 0.015$ & 205.1 & $32.11 @ 26.8^{\circ} \mathrm{C}$ & 30.18 \\
\hline CSB-ME20 & $0.912 \pm 0.015$ & 210.3 & $31.68 @ 26.8^{\circ} \mathrm{C}$ & 31.07 \\
\hline
\end{tabular}




\subsection{Engine Test}

An engine test was performed using a single-cylinder air-cooled Yanmar L48N6 diesel engine (Yanmar, Italy). Engine specification is given in Table 2. A land-and-sea water-brake dynamometer was used to load the engine and to measure the engine speed, torque and break power. The dynamometer was calibrated, and the differences between the dynamometer readings through its software and the real torque applied for calibration were less $\pm 0.1 \mathrm{Nm}$. A Kistler pressure transducer was installed in the engine cylinder head to measure the in-cylinder pressure.

Table 2. Engine specification.

\begin{tabular}{cc}
\hline Engine Type & 4-Stroke, Vertical Cylinder Diesel Engine \\
\hline Displacement & $0.219(\mathrm{litres})$ \\
Continuous Rating Output & $3.09(\mathrm{~kW}) @ 3600(\mathrm{rpm})$ \\
Crankshaft offset & $28.5(\mathrm{~mm})$ \\
Dry Engine Weight & $27(\mathrm{~kg})$ \\
Length & $332(\mathrm{~mm})$ \\
Width & $384(\mathrm{~mm})$ \\
Height & $417(\mathrm{~mm})$ \\
Injection Timing & 16.5 before TDC \\
\hline
\end{tabular}

The tested engine speeds were selected based on the engine performance curves provided by the manufacturer, as well as our preliminary engine tests. The engine speeds were noticed to be unstable at maximum engine load (lower engine speed) and maximum engine speed ( $3800 \mathrm{rpm}$; zero load) when the emulsion fuel was used compared to the pure biodiesel. Therefore, the engine speeds were adjusted to the nearest stable engine speed. Taking into account that these points were not for practical application as the engine would not operate without load and would not operate with maximum load before the engine stopped running, these points were presented to complete the engine performance curves. The most important points were in the middle of the curves, as they represented the maximum engine power, torque and lowest BSFC. Apart from these two points, the engine performance was stable.

The vibration of the engine body was measured using an accelerometer (PCB Model 353-B33 accelerometer) with a sensitivity of $10.19 \mathrm{mV} /\left(\mathrm{m} / \mathrm{s}^{2}\right)$ due to the low noise and voltage output signal compatible with the National Instrument hardware. The accelerometer was connected to the engine using glue and screws. Rubber washers were used between the engine body and the testbed frame to eliminate the vibration transfer to the frame. Figure 2 shows the schematic diagram of the experimental setup. The exhaust gas emission was measured using a CODA gas analyser. The uncertainty of the gas analyser is presented in Table 3.

Table 3. CODA gas analyser accuracy.

\begin{tabular}{cccc}
\hline Measurement & Range & Accuracy & Accuracy \\
\hline \multirow{2}{*}{ n-Hexane } & $0.00-2000 \mathrm{ppm}$ & & $\pm 3 \%$ \\
& $2001-15000 \mathrm{ppm}$ & \pm 4 ppm abs. & $\pm 5 \%$ \\
& $15000-30000 \mathrm{ppm}$ & & $\pm 8 \%$ \\
\hline \multirow{2}{*}{$\mathrm{CO}$} & $0.00-10 \%$ & $\pm 0.02 \%$ abs. & $\pm 3 \%$ \\
& $10.001-15.00 \%$ & $\pm 0.3 \%$ abs. & $\pm 3 \%$ \\
$\mathrm{CO}_{2}$ & $0.00-16 \%$ & $\pm 5 \%$ \\
\hline $\mathrm{O}_{2}$ & $16.01-20 \%$ & $\pm 0.1 \%$ abs. & $\pm 5 \%$ \\
\hline \multirow{2}{*}{$\mathrm{NO}$} & $0.00-25 \%$ & $\pm 20 \mathrm{ppm}$ abs. & $\pm 4 \%$ \\
& $0.00-4 \mathrm{ppm}$ & & $\pm 5 \%$ \\
\hline
\end{tabular}




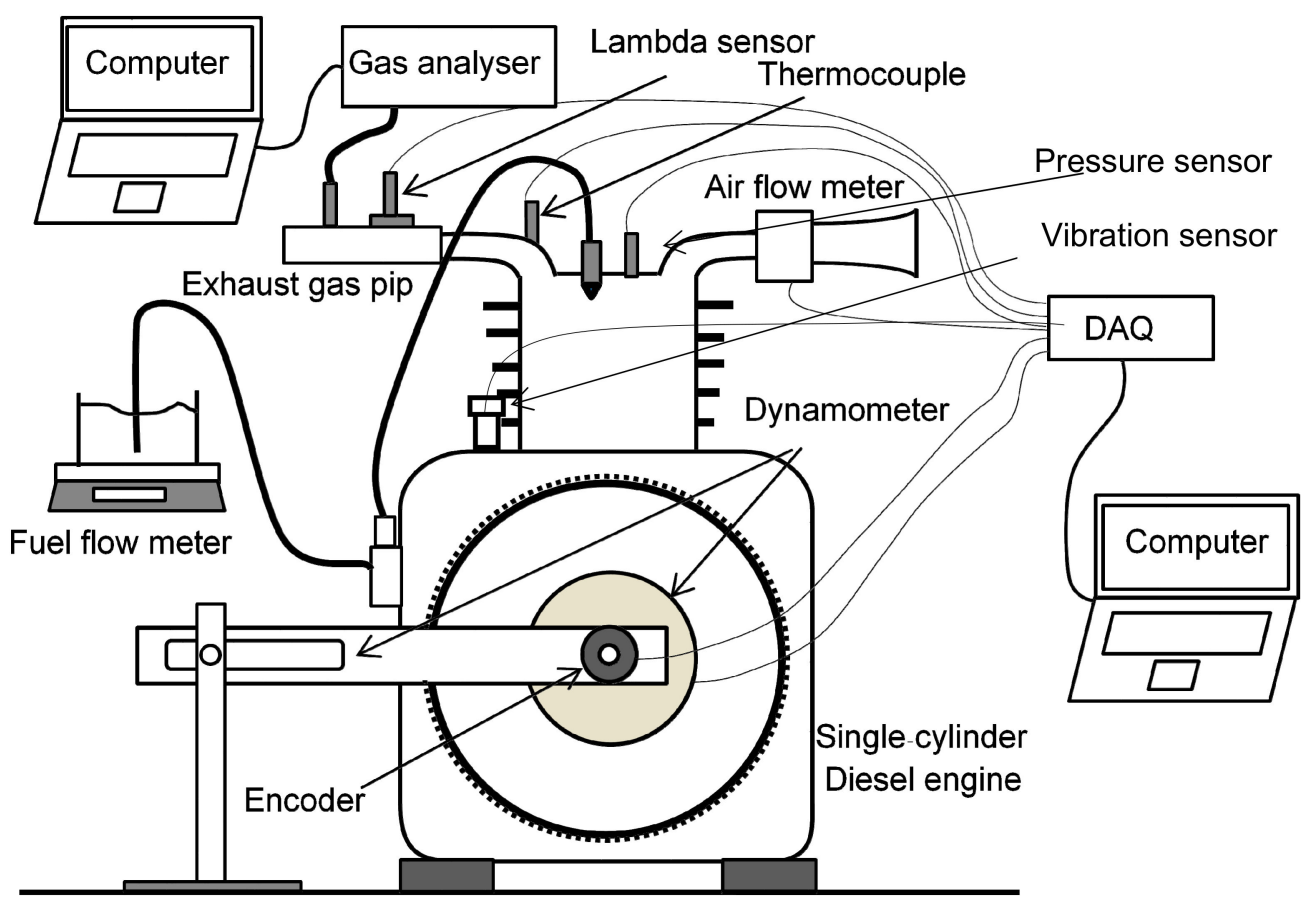

Figure 2. Schematic diagram of the experimental setup.

To avoid the ambient conditions' influence on the engine test result, the data from the weather station linked to the dynamometer software were monitored to ensure that all the tests were performed at relatively similar ambient conditions. The ambient temperature was around $23 \pm 3^{\circ} \mathrm{C}$, and the relative humidity was $44 \pm 8 \%$.

\subsection{Engine Test Procedure}

Five testing points were selected based on the engine specification curves provided by the engine manufacturer and also based on the pre-tests to find the most stable engine speeds close to the engine specification curves at maximum operating conditions. Each test was started by heating up the engine. The test was started with the use of the CS-B100 by setting up the engine at maximum speed (no load) at $3800 \mathrm{rpm}$. Then, the engine was loaded to reach $3670 \mathrm{rpm}$ (the maximum output power). The next point was achieved by adding more load on the engine until the speed dropped to $2900 \mathrm{rpm}$ (the lowest BSFC point). Then, the engine was loaded to achieve $2320 \mathrm{rpm}$ (maximum torque). The last point was at $1770 \mathrm{rpm}$ (maximum smoke density). The test was repeated following the same procedure using CSB-E20 and CSB-ME20. The engine was given a sufficient time at each speed to achieve stable test conditions. The average of a minimum three tests result is plotted in the figures.

The data of the in-cylinder pressure at each point of the engine speed were recorded, and the average of 100 continuous cycles was drawn against the crank angle degree. The focus of this work was on the vibration in the Z-axis (in the piston reciprocated movement direction) only, which was an upward-downward piston. The well-recognised equation developed by Krieger and Borman in Equation 1 has been used widely to calculate heat release [31-38] and was adopted in this work.

$$
\frac{d Q_{n}}{d \theta}=\frac{\gamma}{\gamma-1} p \frac{d v}{d \theta}+\frac{1}{\gamma-1} v \frac{d p}{d \theta}
$$

where $Q_{n}$ is the heat release rate per crank angle $\left(\mathrm{J} /{ }^{\circ} \mathrm{CA}\right), \gamma=$ the ratio of the heat capacity, $p=$ in-cylinder pressure (bar) and $v=$ cylinder volume $\left(\mathrm{cm}^{3}\right)$. 


\section{Results}

\subsection{In-Cylinder Pressure, Vibration and Heat Release Analysis}

The in-cylinder pressure that occurs at the power stroke is important for identifying the indicated engine performance and is correlated to the engine vibration. Based on the engine manufacturer's data, fuel injection starts at $16.5^{\circ}$ before top dead centre (BTDC) $\left(360^{\circ}\right)$, as marked in the pressure and heat release rate figures. The in-cylinder pressure at the engine speed of $3670 \mathrm{rpm}$ is presented in Figure 3. At the crank angle of 343.5 (the injection point), the pressure produced from the emulsion fuels was lower than that of the CS-B100. It is known that, before $343.5^{\circ}$, the charge in the cylinder is mainly air. The air temperature in the combustion chamber depends on the engine temperature. The engine temperature is lower when run with emulsion fuels; therefore, the pressure for the charge before the injection was expected to be lower than that of the base fuel. The peak pressure (60.7 bar) was found with CS-B100 to be higher than that of CSB-E20 by $16.2 \%$. Adding microalgae powder to the emulsion fuel increased the peak pressure from 50.87 bar to 56.92 bar for the CSB-E20 and CSB-ME20, respectively.

The main reason for the drops in pressure was the higher viscosity and lower heating value of the emulsion fuels, which were 30.18 and $31.07 \mathrm{MJ} / \mathrm{kg}$ for CSB-E20 and CSB-ME20, respectively, and $39.3 \mathrm{MJ} / \mathrm{kg}$ for CS-B100 (Table 1). Adding microalgae to the emulsion fuel enhanced the peak in-cylinder pressure significantly.

Figure 4 shows the relationship between the heat release rate $\left(\mathrm{J} /{ }^{\circ} \mathrm{CA}\right)$ against the engine crank angle at an engine speed of $3670 \mathrm{rpm}$. From Figures 3 and 4, it can be observed that the heat release rate curves were less for both emulsion fuels. This figure also depicts that the heat release had the same pattern as the in-cylinder pressure. The maximum heat release rate was recorded with CS-B100 (49.8 J/ $\left.{ }^{\circ} \mathrm{CA}\right)$, followed by CSB-ME20 $\left(48.35 \mathrm{~J} /{ }^{\circ} \mathrm{CA}\right)$ and then CSB-E20 (46.25 J/ $\left.{ }^{\circ} \mathrm{CA}\right)$. Figure 4 also shows that the there was no significant ignition delay recorded (from the injection start of $16.5^{\circ} \mathrm{CA}$ BTDC to the start of ignition) for all fuels and that it kept the same till $365{ }^{\circ} \mathrm{CA}$. Tesfa et al. [39] also reported insignificant ignition delay when water was injected in fuel.

These findings are in agreement with the findings of FahdWenming [18] that the in-cylinder pressure for ED10 was slightly lower than that of the diesel due to the lower heating value and due to the presence of water in diesel, which absorbed heat and consequently reduced the combustion temperature.

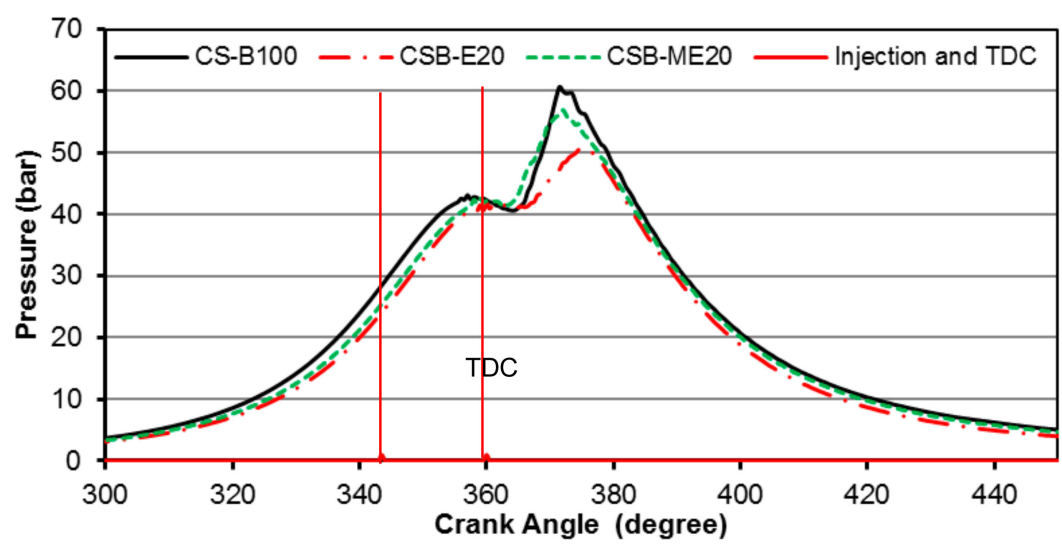

Figure 3. In-cylinder pressure at an engine speed of $3670 \mathrm{rpm}$. 


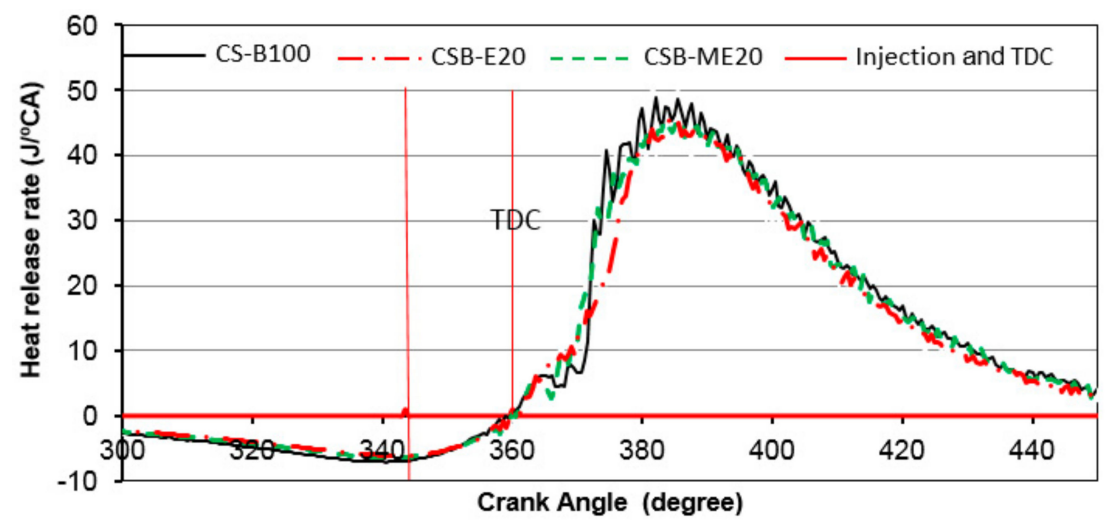

Figure 4. Heat release rate $\left(\mathrm{J} /{ }^{\circ} \mathrm{CA}\right)$ at an engine speed of $3670 \mathrm{rpm}$.

In this study, the focus was on the vibration due to the fuels' combustion only. The vibration of the three fuels was analysed using MATLAB, R 2018B (Mathworks). Fast Fourier transform algorithm, which decomposes a sequence of $(\mathrm{N})$ vibration signal values obtained from the accelerometer into the components of frequencies. The frequencies related to the combustion process (combustion stroke at the tested engine speed) were kept, and all other high and low frequencies were eliminated. Then, the data were converted back to the time domain using inverse fast Fourier transform and plotted against the engine crack angle. Another filter was applied to eliminate the noise from the vibration signal and find the absolute vibration. The effect of the water of the emulsion fuels on the engine vibration behaviour was confirmed, as shown in Figure 5. In this figure, it is clear that the vibration curves were strongly correlated to the in-cylinder pressure. The maximum acceleration was around $120 \mathrm{~m} \cdot \mathrm{s}^{-2}$ when the engine fuelled with CS-B100, and CSB-E20 produced a peak vibration almost half of that value. The differences of the acceleration values for different fuels were considered to be significant. The high vibration values were maximum at higher engine speeds.

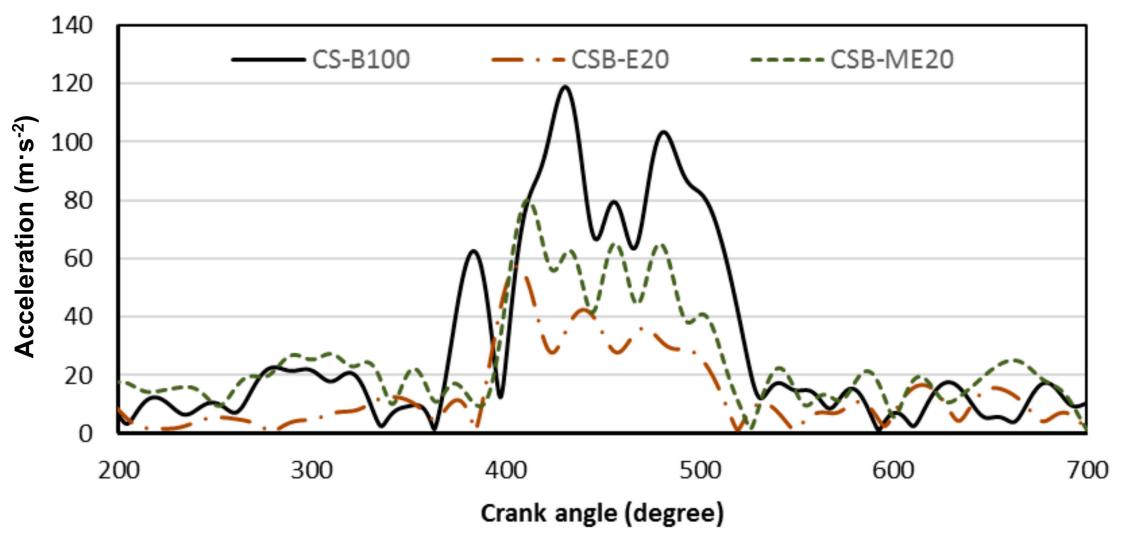

Figure 5. Vibration at engine speed $3670 \mathrm{rpm}$.

Figures 6-8 show the engine combustion and vibration properties at an engine speed of $2900 \mathrm{rpm}$ of the in-cylinder pressure, heat release rate and vibration, respectively. Figure 6 depicts a reduction percentage in the peak in-cylinder pressure compared to CS-B100 of $13.23 \%$ and $9.31 \%$ for CSB-E20 and CSB-ME20, respectively. However, for the emulsion fuel containing 20\% water, the reduction in the peak pressure was less than $14 \%$. The results are in agreement with those of FahdWenming [18], which indicated that the reduction percentage in the in-cylinder pressure with emulsion fuel was less than the percentage of water in the emulsion fuel because of the better combustion. 


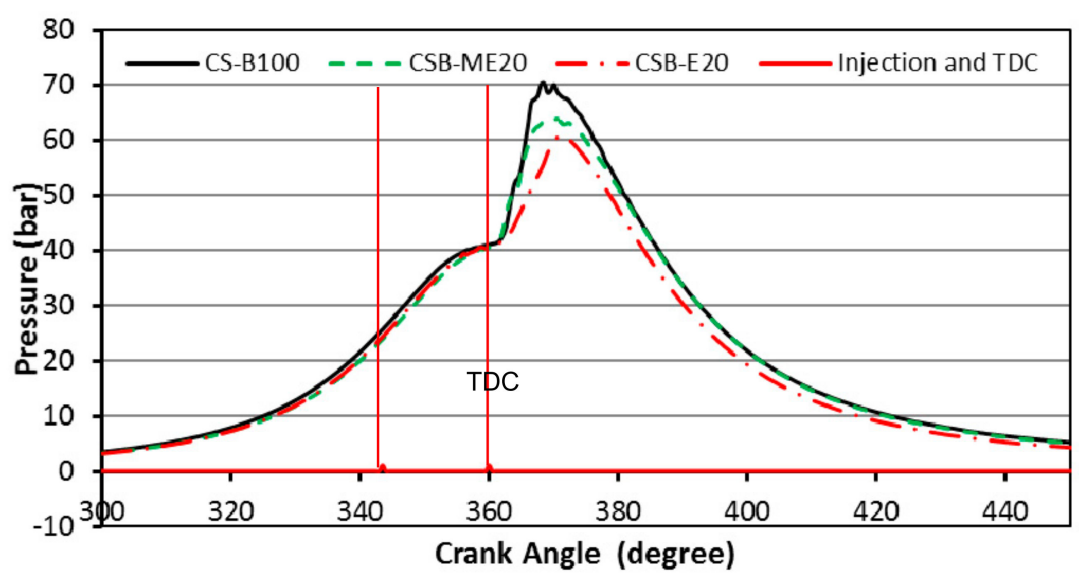

Figure 6. In-cylinder pressure at an engine speed of $2900 \mathrm{rpm}$.

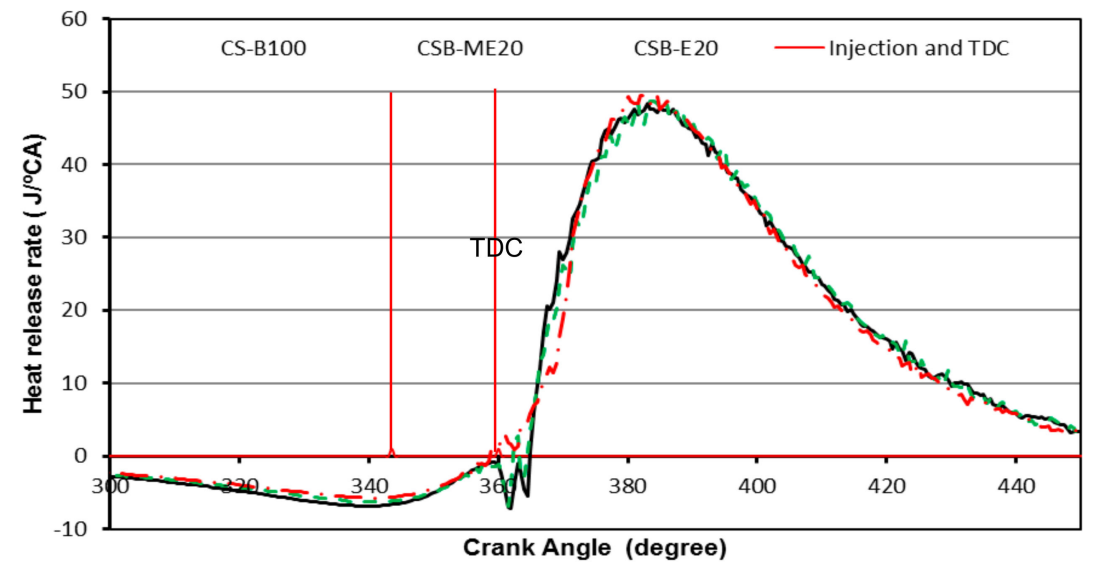

Figure 7. Heat release rate $\left(\mathrm{J} /{ }^{\circ} \mathrm{CA}\right)$ at an engine speed of $2900 \mathrm{rpm}$.

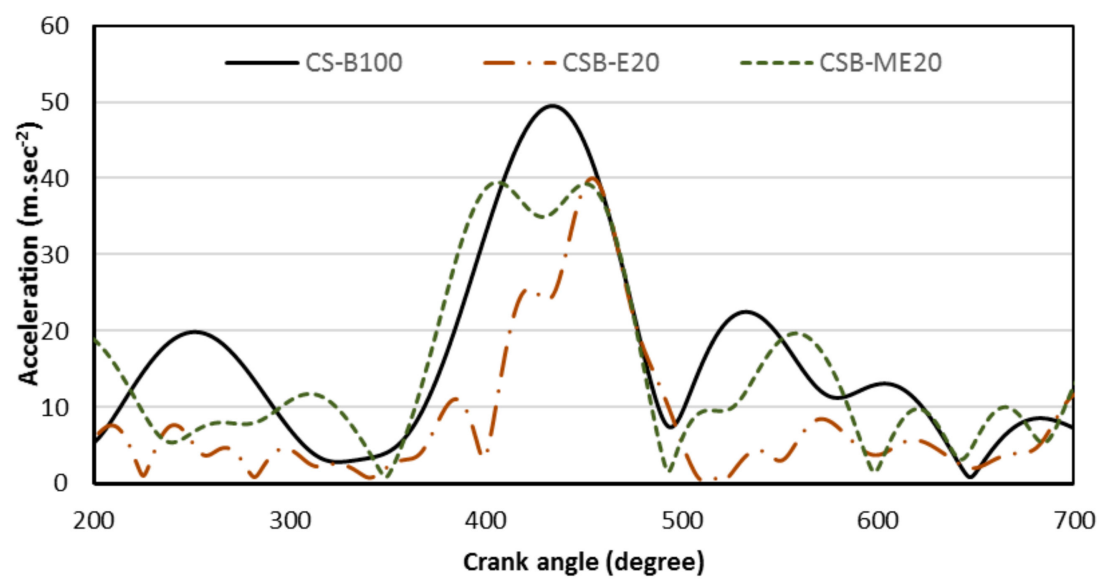

Figure 8. Vibration at an engine speed of $2900 \mathrm{rpm}$.

Figure 7 shows the heat release rate $\left(\mathrm{J} /{ }^{\circ} \mathrm{CA}\right)$ at an engine speed of $2900 \mathrm{rpm}$ for the three tested fuels. Heat release from CSB-100 was similar to the emulsion fuels with and without microalgae. The difference between the peak heat release rate of CS-B100 and CSB-E20 was $1.43 \%$. Figure 8 indicates no ignition delay up to the TDC. After the TDC, the CSB-E20 heat release rate was slightly higher compared to CSB-100 by $2.98 \%$. This is in agreement with [39].

The relationship between the engine vibration and the crank angle at an engine speed of $2900 \mathrm{rpm}$ is presented in Figure 8. It can be seen that the peaks of the acceleration from the three fuels were in agreement with the results obtained from the in-cylinder pressure at this speed. CS-B100 produced the 
highest value of acceleration of $49.4 \mathrm{~m} \cdot \mathrm{s}^{-2}$, and both CSB-E20 and CSB-ME20 produced lower vibration than the pure biodiesel with peak values around $40 \mathrm{~m} \cdot \mathrm{s}^{-2}$. CSB-ME20 produced a peak vibration value similar to CSB-E20 as the peak in-cylinder pressure at this speed for these two fuels was relatively the same. It can be noticed from Figures 5 and 8 that the peak acceleration values at an engine speed of $2900 \mathrm{rpm}$ were significantly lower than the values at $3670 \mathrm{rpm}$ due to the lower engine rotating speed and higher load on the engine.

\subsection{Engine Performance}

\subsubsection{Brake Power}

Figure 9 shows the test results for the break power curves produced using CS-B100, CSB-E20 and CSB-ME20 at different engine speeds. The maximum break power for the emulsion fuels was found to be predictably lower than for CS-B100. For all fuels, the break power increased as the engine speed increased, reaching the maximum at around $2320 \mathrm{rpm}$ for the emulsion fuels and $2900 \mathrm{rpm}$ for the base fuel. At a lower engine speed of around $1800 \mathrm{rpm}$, all fuels presented relatively close brake power. It can be observed that the differences in brake power between CSB-E20 and CSB-ME20 in comparison with CS-B100 were significant, excluding the brake power at the speeds around 2320 $\mathrm{rpm}$. The maximum differences of $0.79 \mathrm{~kW}$ occurred at $2900 \mathrm{rpm}$ between CS-B100 and CSB-E20. This finding shows some degree of agreement with $[18,40]$ and [26] in terms of the reduction in power due to the emulsified water. The reason for the reduction was justified by the lower heating value. However, the high reduction percentage in power of $24.8 \%$ can be attributed to the high mechanical losses resulting from the high speed and the extra power required for injecting a more viscous fuel. Another factor that caused this reduction was the high value of the surface tension of the emulsion without microalgae $(32.105 \mathrm{mN} / \mathrm{m})$ [30]. This high value could have generated a higher droplet size of CSB-E20 in the injection process in comparison with the base fuel. The larger the droplet size, the lower the contact surface area between the droplets and air, which results in more energy being absorbed to evaporate and a longer chemical reaction time, whereas the time for reaction should be short, especially at high engine speeds.

With regard to the comparison of the engine brake power of emulsions, Figure 9 shows that supplementing the emulsion fuel with FWM-CV significantly enhanced the break power. The maximum difference of $19.4 \%$ between the emulsion fuels CSB-E20 and CSB-ME20 occurred at $2320 \mathrm{rpm}$. The reason behind this difference could be the energy content of the segregated microalgae cells that resulted from ultrasound treatment, which reduced the size of the droplet during the injection process. When the fuel that contained biodiesel, water, surfactant and microalgae cells and cell fragments was injected, the fuel droplets consisting of these components were sprayed from the injector at different speeds based on their inertia (size and mass). This inertia difference may have broken down the larger droplets. As reported by [7], the interface of oil in the presence of water leads to finer droplets.

Figure 9 shows that at $2320 \mathrm{rpm}$, CSB-ME20 produced higher power in comparison to CS-B100. This increase in power was due to the fuel viscosity and the fuel charge. The maximum engine torque (from the engine specification sheet) was around $2600 \mathrm{rpm}$. This can be shifted as $2600 \mathrm{rpm}$ was a peak point (unstable and difficult to be practically achieved), and the engine was tuned to run with diesel fuel and not the emulsion. With CSB-ME20, the maximum power was located at $2320 \mathrm{rpm}$. This shift can be due to the fuel specification such as high viscosity and surface tension. This maximum power of CSB-ME20 at 2320 rpm was lower than the maximum power from CSB-B100, which was found to be at $2900 \mathrm{rpm}$. The general outcomes presented in Figure 9 were inconsistent with the results of [22] and [19]. Davis Johnson [22] found that emulsion fuel produced more power than net biodiesel fuel at all engine speeds in spite of the $11.1 \%$ lower heating value of the emulsion fuel. 


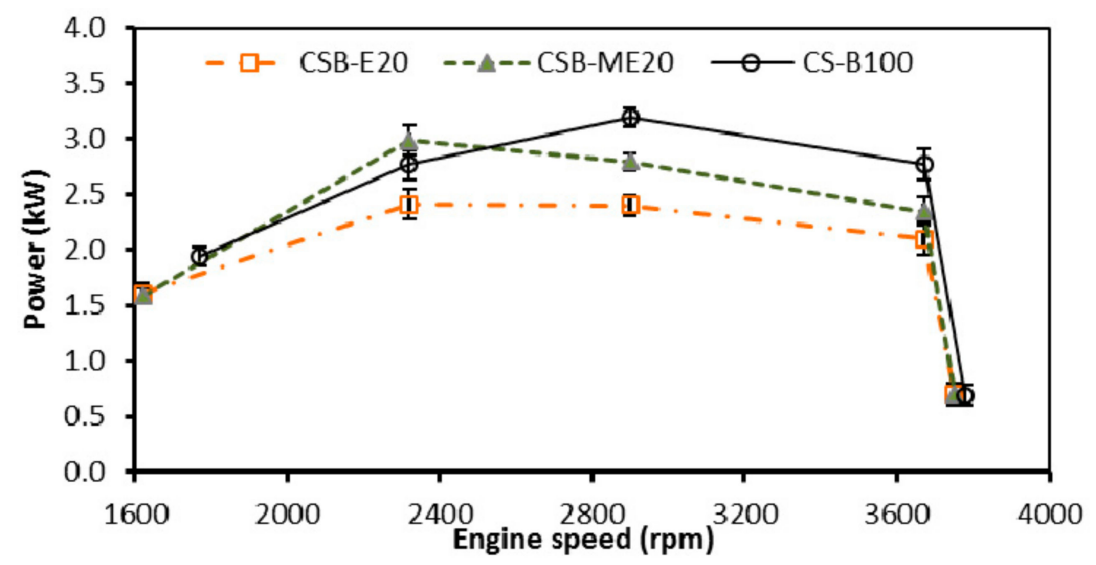

Figure 9. The relationship between engine speeds (rpm) and engine brake power $(\mathrm{kW})$ for CS-B100, CSB-E20 and CSB-ME20.

\subsubsection{Engine Brake Specific Fuel Consumption}

The relationship between the BSFC expressed in $\mathrm{g} / \mathrm{kW} \cdot \mathrm{h}$ and the engine speed for CS-B100, CSB-E20 and CSB-ME20 is shown in Figure 10. It can be observed that the BSFC was nearly constant for the engine speeds below $2320 \mathrm{rpm}$ for all the fuels. BSFC is a function of the brake power and the FC rate; therefore, the lower BSFC was found to be around $2900 \mathrm{rpm}$, in which the maximum power was recorded. FahdWenming [18] stated that the lower BSFC was found to be in the middle range of engine speed because of the higher heat losses to the cylinder wall at low speed and higher friction losses at high speed. The lowest BSFC $(284.2 \mathrm{~g} / \mathrm{kW} \cdot \mathrm{h})$ was produced when CS-B100 was used, which was lower than $364.58 \mathrm{~g} / \mathrm{kW} \cdot \mathrm{h}$ and $333.27 \mathrm{~g} / \mathrm{kW} \cdot \mathrm{h}$ for CSB-E20 and CSB-ME20, respectively. These results matched the results of $[18,26]$, who recorded a decline in the brake power with emulsion fuels, and were not consistent with [19] and [22], who found higher brake power with emulsion fuels.

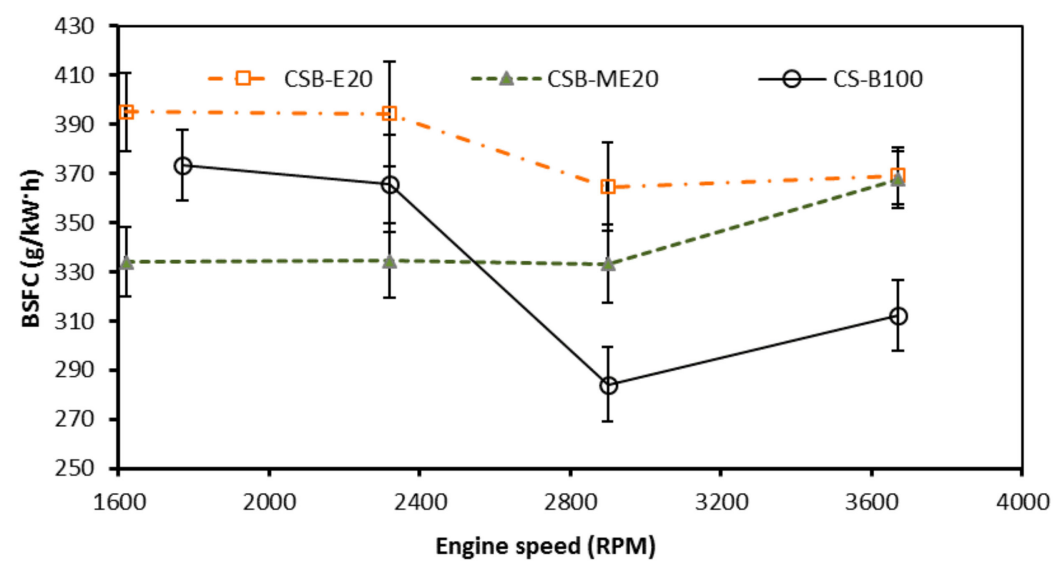

Figure 10. The relationship between engine speeds (rpm) and BSFC $(\mathrm{g} / \mathrm{kW} \cdot \mathrm{h})$ for CS-B100, CSB-E20 and CSB-ME20.

The maximum increase in the BSFC occurred at $2900 \mathrm{rpm}$ between CS-B100 and CSB-E20, which was about $28 \%$. This high variation was due to the water content in the fuel, which reduced the heating value of the emulsion, and due to the high viscosity that resisted the fuel flow in the engine piping system. It was also due to the relatively high standard deviation that referred to differences between the readings for the same conditions between the repeated tests. At all others engine speeds, the variation was less than the reduction of $23.2 \%$ and $20.9 \%$ that came from the reduction in the heating value of CSB-E20 and CSB-ME20, respectively. NadeemRangkuti [15] and Dantas NetoFernandes [24] reported an increase in the BSFC associated with emulsion fuel as compared with PD, which is in agreement with the BSFC results presented in Figure 10. In order to produce a required brake power 
output from lower heating value fuel, it is necessary for extra fuel to be injected, which raises the BSFC values, as is the case with emulsion fuels $[12,26]$. CSB-ME20 presented a significant enhancement in BSFC of about $17.7 \%$ and $9.4 \%$ in comparison with CSB-E20 fuel for the engine speeds of $2320 \mathrm{rpm}$ and $2900 \mathrm{rpm}$, respectively. This may have been caused the existence of FWM-CV, which increased the thermal efficiency and enriched the heating value.

\subsubsection{Exhaust Gas Temperature}

The engine exhaust temperatures for CS-B100, CSB-E20 and CSB-ME20 are depicted in Figure 11. For all fuels, the exhaust gas temperature increased with the increase in the engine speed until a peak temperature was reached, after which it decreased to the lowest value at maximum speed (engine at no load). The peak temperatures varied depending on the fuel type used. The trend of exhaust gas temperatures showed agreement with [26]. The maximum temperature of $507^{\circ} \mathrm{C}$ was reached at $2320 \mathrm{rpm}$ for the base fuel due to the maximum torque achieved at this speed. The maximum fuel flow rate associated with the lower speed offers extra time for the reaction and temperature to rise [26].

At most engine speeds, CSB-E20 and CSB-ME20 demonstrated a decline in the exhaust gas temperature compared with the base fuel. This is consistent with the results shown in Figures 3, 4, 6 and 7 for the in-cylinder pressure and heat release in which the emulsion fuels produced lower heat because of the lower heating value. This phenomenon was also caused by the water content, which absorbed some combustion process heat $[18,26]$. In a study by ScraggMorrison [20], the use of emulsified water containing microalgae fuel reduced the exhaust gas temperature by $47^{\circ} \mathrm{C}$ compared with biodiesel fuel.

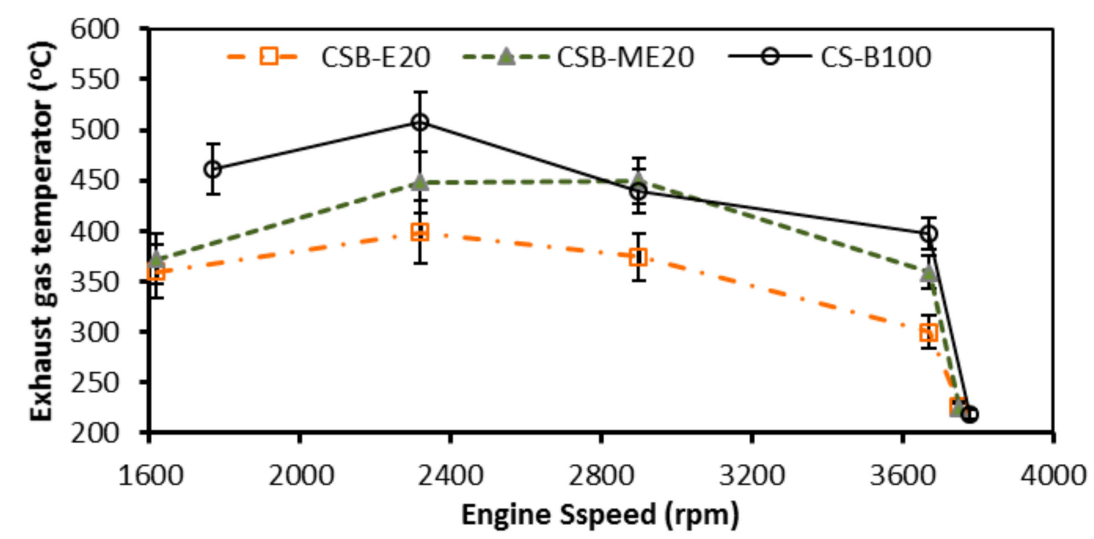

Figure 11. The relationship between engine speeds (rpm) and exhaust gas temperature $\left({ }^{\circ} \mathrm{C}\right)$ for CS-B100, CSB-E20 and CSB-ME20.

\subsection{Exhaust Gas Emissions}

\subsubsection{Carbone Monoxide}

The percentage of CO emissions at different engine speeds for CS-B100, CSB-E20 and CSB-ME20 are presented in Figure 12. The CO percentage was considerably decreased when the engine speed increased for all fuels. The maximum CO percentage occurred with CS-B100 fuel up to $2320 \mathrm{rpm}$. For the low speeds and high loads, the level of CO was 3.55\% for CS-B100 compared with $2.0 \%$ for CSB-E20 and $1.93 \%$ with CSB-ME20. The lower CO level for the emulsified fuels at low speed was caused by the increase in the thermal efficiency due to the available time for complete combustion and converting $\mathrm{CO}$ to $\mathrm{CO}_{2}$. All fuels showed a reduction in the $\mathrm{CO}$ percentage at high engine speeds. This sharp transition, which occurred at speeds above $2320 \mathrm{rpm}$, may have been caused by the improved combustion resulting from increased in-cylinder pressure. According to Koc and Abdullah [26], the water content in fuel contributed to reducing the $\mathrm{CO}$ level because of the increased percentage of $\mathrm{OH}$, which enhanced the chance to form $\mathrm{CO}_{2}$. Similarly, NadeemRangkuti [15] reported that the water in biodiesel facilitates 
extra micro-explosions that enhance the mixing process. This reduction agrees with the results of [41] and [18] for low load. However, the results disagree with [42] and the finding of [18] that the CO level at high engine load was insignificant.

As Figure 12 shows, there was a higher $\mathrm{CO}$ level at high load (low speed). This is in agreement with the results of [7]. The reduced CO percentage was confirmed by the test result on thermal efficiency, which decreased at high engine load. This may also be linked to the fact that the emulsion fuels contained $20 \%$ water with a lesser carbon to $\mathrm{O}_{2}$ ratio, which allowed the $\mathrm{CO}$ to form $\mathrm{CO}_{2}$ at low speed. At $2900 \mathrm{rpm}$, CSB-E20 and CSB-ME20 produced a low value and almost the same CO level that was produced by CS-B100 due to the access amount of air in the combustion chamber (lean combustion), which means the quality of combustion was expected to be complete. However, at low speed, the CO level was high due to rich and incomplete combustion, as well as a small lambda at low engine speed. The $\mathrm{CO}$ plateaued at a very low level because of the excess $\mathrm{O}_{2}$ and turbulent mixing combustion as the speed increased. The results showed agreement with the findings of [20] when the engine was operated with emulsified fuel containing microalgae at low load for speeds below $2900 \mathrm{rpm}$. The variation in their results between the emulsified fuel and the base fuel was found to be higher than that presented in Figure 12. The most likely reason for that difference is the different engine design and the operating conditions.

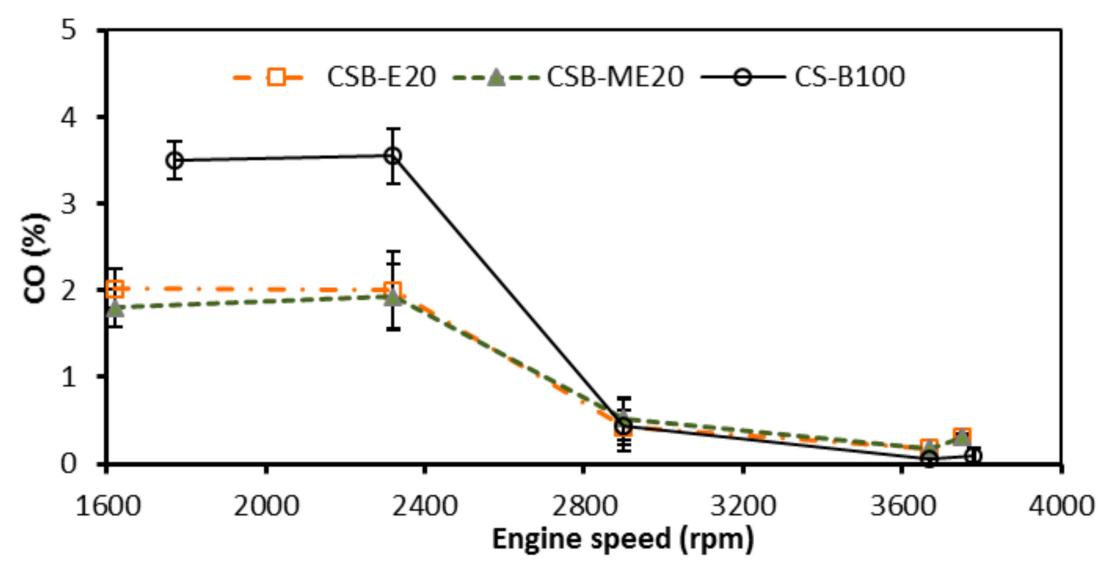

Figure 12. The relationship between engine speeds (rpm) and CO (\%) for CS-B100, CSB-E20 and CSB-ME20.

\subsubsection{Carbone Dioxide}

The $\mathrm{CO}_{2}$ level emitted from CS-B100, CSB-E20 and CSB-ME20 is plotted against the engine speed in Figure 13. From this figure, it can be observed that the CSB-E20 and CSB-ME20 produced lower $\mathrm{CO}_{2}$ at all engine speeds. Similarly, Bidita et al. [42] reported a reduction in the $\mathrm{CO}_{2}$ level when emulsified water in diesel fuel was used. ScraggMorrison [20] also noticed a slight decline in the $\mathrm{CO}_{2}$ percentage in the exhaust produced from emulsion fuel containing microalgae compared with biodiesel fuel. The opposite finding was reported by [26], who reported that emulsion fuel emitted higher $\mathrm{CO}_{2}$, possibly because of the higher $\mathrm{O}_{2}$ in the emulsified water fuels.

The results also confirmed that adding FWM-CV to the emulsion fuel increased the $\mathrm{CO}_{2}$ when comparing CSB-ME20 with CSB-E20. This was mainly because of the higher fuel injected with CSB-ME20 associated with better combustion, which allowed $\mathrm{CO}$ to be converted to $\mathrm{CO}_{2}$. 


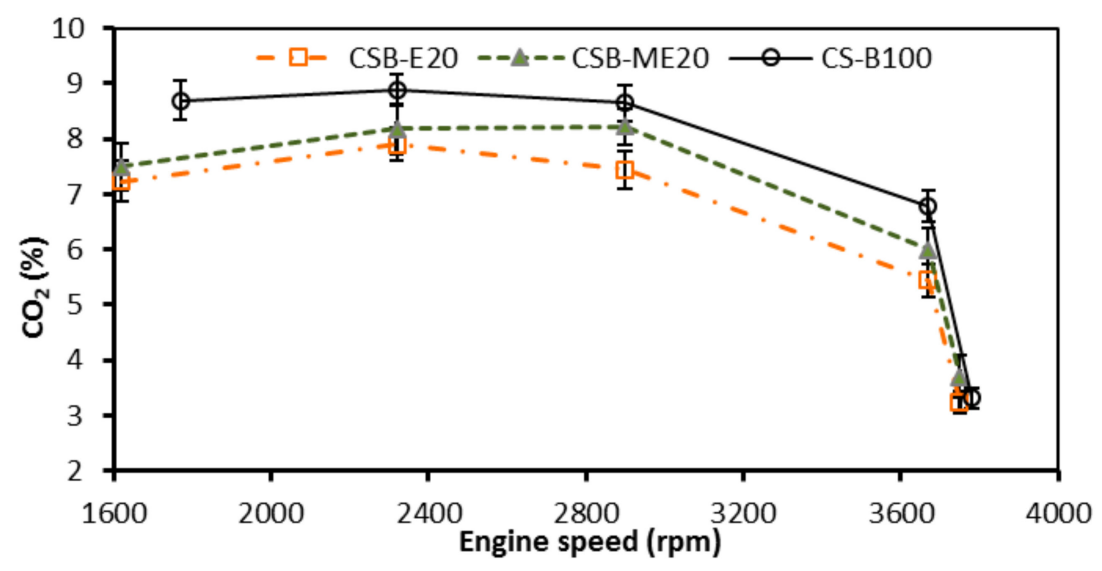

Figure 13. The relationship between engine speeds (rpm) and $\mathrm{CO}_{2}(\%)$ for CS-B100, CSB-E20 and CSB-ME20.

\subsubsection{Oxygen $\left(\mathrm{O}_{2}\right)$ and Lambda}

Figures 14 and 15 show the effect of the engine speed on the $\mathrm{O}_{2}$ percentage and lambda for the engine fuelled by CS-B100, CS-E20 and CS-ME20 fuels. As the diesel engine in most cases ran lean, that is a higher air/fuel ratio than stoichiometric, the air/fuel ratio, the in-cylinder pressure turbulence, time of reaction, the droplet size and the spray pattern were all important factors affecting the chemical kinetic reaction of carbon with the available oxygen. It can be seen that the higher the engine speed, the higher the excess $\mathrm{O}_{2} \%$ and lambda values. Reducing the engine speed (applying extra load) increased the reaction time. The shorter time reduced the in-cylinder turbulence, which reduced the combustion efficiency and increased the fuel usage, resulting in an increased lower air/fuel ratio. Similar findings and justifications were reported by Koc and Abdullah [26]. The lower heating value in the emulsion fuels required less oxygen for the combustion process, contributing to the higher excess $\mathrm{O}_{2}$ from the CS-E20 and CS-ME20 fuels than the CS-B100 fuel. As a result of the presence of the extra hydrocarbon provided by FWM-CV in the CS-ME20 compared to CS-E20 fuel, the $\mathrm{O}_{2}$ level was slightly lower. The $\mathrm{O}_{2}$ level in Figure 14 especially at 3670 rpm agreed with ScraggMorrison [20], in which the $\mathrm{O}_{2}$ increased from $13.3 \%$ with neat biodiesel to $13.9 \%$ when the emulsion fuel was implemented.

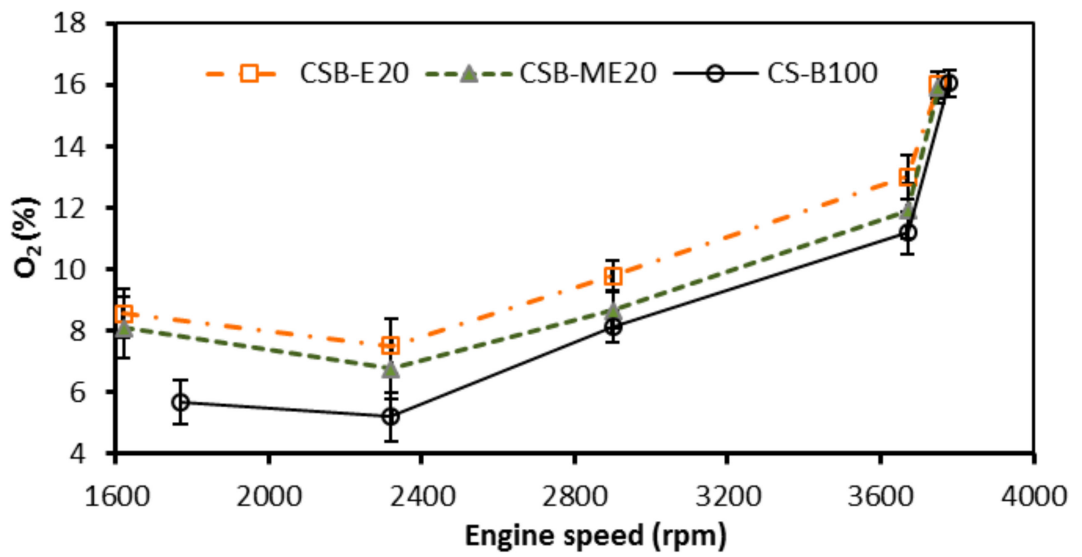

Figure 14. The relationship between engine speeds (rpm) and $\mathrm{O}_{2}(\%)$ for CS-B100, CSB-E20 and CSB-ME20. 


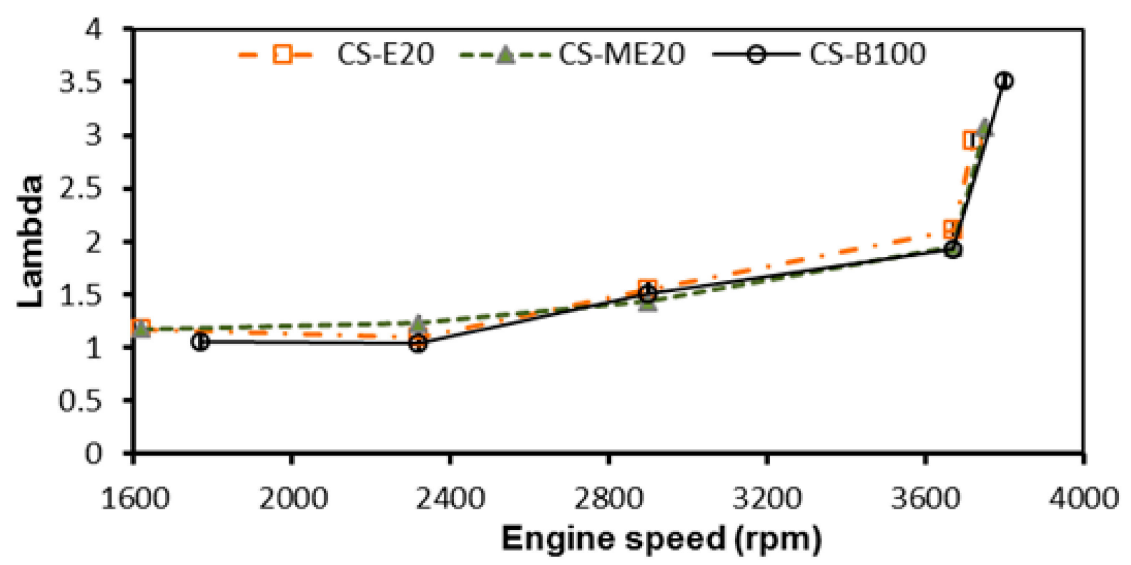

Figure 15. The relationship between engine speeds (rpm) and lambda for CS-B100, CSB-E20 and CSB-ME20.

\subsubsection{Nitrogen Oxides}

The $\mathrm{NO}_{\mathrm{x}}$ emission produced by the engine utilising CS-B100, CSB-E20 and CSB-ME20 fuel as a function of engine speed is represented in Figure 16. The significant differences between the test fuels can be clearly observed at all engine speeds. The maximum reduction occurred at $2900 \mathrm{rpm}$. The $\mathrm{NO}_{\mathrm{x}}$ level fell from $505 \mathrm{ppm}$ with CS-B100 to $378 \mathrm{ppm}$ and $339 \mathrm{ppm}$ for CSB-E20 and CSB-ME20 with a reduction of $25.14 \%$ and $32.87 \%$, respectively. Maiboom and Tauzia [8] reported a similar reduction of up to $50 \%$ of $\mathrm{NO}_{\mathrm{x}}$ when using emulsified water and exhaust gas recycling. The use of water emulsion fuel reducing the $\mathrm{NO}_{x}$ emission was also found by $[14,27,42]$. The water content in the emulsion fuels generated a heat sink, which lowered the combustion temperature and retarded the $\mathrm{NO}_{\mathrm{x}}$ formation $[8,18]$. Supporting results were found by [26]. The $\mathrm{NO}_{\mathrm{x}}$ reduction was caused by the presence of the water droplets, which reduced the combustion temperature and the increased the $\mathrm{OH}$ formation [22]. The specific $\mathrm{NO}_{\mathrm{x}}$ emissions produced from emulsion of $10 \%$ water in biodiesel were found to be significantly lower than those emitted by B100 in spite of the insignificant difference in the exhaust gas temperature compared to that produced from B100 [22]. This reduction was linked to the increase in the percentage of $\mathrm{OH}$ radicals in the emulsion fuel, which was in agreement with the findings of this work. At the engine speeds of $3670 \mathrm{rpm}$ and $2320 \mathrm{rpm}$, the reduction in the $\mathrm{NO}_{\mathrm{x}}$ level showed very strong agreement with the reduction found by [20] when compared with biodiesel fuel.

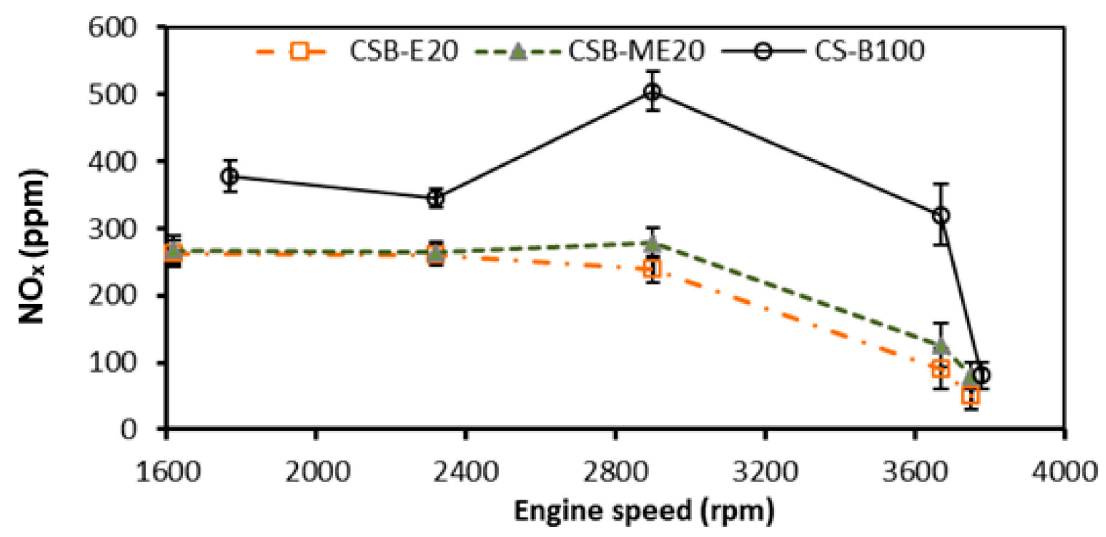

Figure 16. The relationship between engine speeds (rpm) and $\mathrm{NO}_{\mathrm{x}}(\mathrm{PPM})$ for CS-B100, CSB-E20 and CSB-ME20.

\section{Conclusions}

This paper discussed the testing of three types of fuels in a single-cylinder diesel engine. The fuels were pure cottonseed biodiesel (CS-B100), emulsified water fuel containing 20\% water in CS-B100 
(CSB-E20) and emulsified fuel containing 20\% water with FWM-CV added (CSB-ME20). The results of the engine performance and emission tests can be concluded as follows:

1. The in-cylinder pressure and the heat release for the emulsion fuels showed no ignition delay. The emulsion fuels indicated lower in-cylinder pressure than the $100 \%$ biodiesel, and this led to a lesser vibration maximum value.

2. In general, CSB-E20 resulted in lower values than CSB-ME20, and both were lower than CS-B100 in brake power, $\mathrm{CO}_{2}$ and $\mathrm{NO}_{\mathrm{x}}$. In contrast, CSB-E20 resulted in higher values than CSB-ME20, and both were higher than CS-B100 in BSFC and $\mathrm{O}_{2}$. The emulsion fuels gave higher and lower values than the base fuel in $\mathrm{CO}$ and the thermal efficiency depending on the engine load and speed.

Author Contributions: Conceptualization, Methodology S.H.A.-l. and T.Y.; Software, K.S.; Validation S.H.A.-1., T.Y., K.S. and B.Y.; Formal Analysis, S.H.A.-1.; Writing-Original Draft Preparation, and Writing-Review \& Editing, S.H.A.-1., T.Y., K.S. and B.Y.

Funding: This research received no external funding.

Acknowledgments: The authors thank the Iraqi government, Ministry of Higher Education and Scientific Research, and the University of Southern Queensland (USQ), Australia, for supporting and funding this research.

Conflicts of Interest: The authors declare no conflict of interest.

\section{Abbreviations}

$\begin{array}{ll}\text { ATDC } & \text { After top dead centre } \\ \text { BTDC } & \text { Before top dead centre } \\ \text { BP } & \text { Brake power } \\ \text { BSFC } & \text { Brake specific fuel consumption } \\ { }^{\circ} \mathrm{C} & \text { degrees Celsius } \\ \mathrm{CO} & \text { Carbone monoxide } \\ \mathrm{CO}_{2} & \text { Carbone dioxide } \\ \mathrm{CS}_{-} \mathrm{B} 100 & \text { Pure cottonseed biodiesel 100\% } \\ \text { CSB-E20 } & \text { Cottonseed biodiesel with emulsified water 20\% } \\ \mathrm{CSB}-\mathrm{ME} 20 & \text { Cottonseed biodiesel with emulsified water 20\% containing FWM-CV } \\ \mathrm{CV} & \text { Chlorella vulgaris } \\ \text { FAME } & \text { Fatty acid methyl ester } \\ \mathrm{FWM-CV} & \text { Fresh water microalgae Chlorella vulgaris } \\ \mathrm{HC} & \text { Hydrocarbons } \\ \text { LHV } & \text { Lower heating value } \\ \mathrm{MJ} & \text { Mega joule } \\ \mathrm{NO} & \text { Nitrogen oxides } \\ \mathrm{O}_{2} & \text { Oxygen } \\ \mathrm{PD} & \text { Petroleum diesel } \\ \mathrm{rpm} & \text { Revolutions per minute } \\ \mathrm{T} & \text { Temperature (also torque) } \\ \mathrm{TDC} & \text { Top dead centre } \\ \mu \mathrm{m} & \text { Micrometre, micron } \\ \theta & \text { Crankshaft angular displacement from TDC } \\ & \end{array}$

\section{References}

1. Lin, C.-Y.; Chen, L.-W. Engine performance and emission characteristics of three-phase diesel emulsions prepared by an ultrasonic emulsification method. Fuel 2006, 85, 593-600. [CrossRef]

2. Rahman, M.M.; Hassan, M.H.; Kalam, M.A.; Atabani, A.E.; Memon, L.A.; Rahman, S.M.A. Performance and emission analysis of Jatropha curcas and Moringa oleifera methyl ester fuel blends in a multi-cylinder diesel engine. J. Clean. Prod. 2014, 65, 304-310. [CrossRef] 
3. Yang, P.-M.; Lin, K.C.; Lin, Y.-C.; Jhang, S.-R.; Chen, S.-C. Emission evaluation of a diesel engine generator operating with a proportion of isobutanol as a fuel additive in biodiesel blends. Appl. Therm. Eng. 2016, 100, 628-635. [CrossRef]

4. Armas, O.; Ballesteros, R.; Martos, F.; Agudelo, J. Characterization of light duty diesel engine pollutant emissions using water-emulsified fuel. Fuel 2005, 84, 1011-1018. [CrossRef]

5. Yusaf, T.F.; Yousif, B.F.; Elawad, M.M. Crude palm oil fuel for diesel-engines: Experimental and ANN simulation approaches. Energy 2011, 36, 4871-4878. [CrossRef]

6. Lin, C.-Y.; Lin, H.-A. Diesel engine performance and emission characteristics of biodiesel produced by the peroxidation process. Fuel 2006, 85, 298-305. [CrossRef]

7. Lif, A.; Holmberg, K. Water-in-diesel emulsions and related systems. Adv. Colloid Interface Sci. 2006, 123-126, 231-239. [CrossRef]

8. Maiboom, A.; Tauzia, $\mathrm{X} . \mathrm{NO}_{\mathrm{x}}$ and PM emissions reduction on an automotive HSDI Diesel engine with water-in-diesel emulsion and EGR: An. experimental study. Fuel 2011, 90, 3179-3192. [CrossRef]

9. Park, J.; Huh, K.; Park, K. Experimental study on the combustion characteristics of emulsified diesel in a rapid compression and expansion machine. Proc. Inst. Mech. Eng. Part D J. Automob. Eng. 2000, 214, 579-586. [CrossRef]

10. Hansen, A.; Gratton, M.; Yuan, W. Diesel engine performance and $\mathrm{NO}_{X}$ emissions from oxygenated biofuels and blends with diesel fuel. Trans. ASABE 2006, 49, 589-595. [CrossRef]

11. McCormick, R.L.; Alleman, T.L. Effect of Biodiesel Fuel on Pollutant Emissions from Diesel Engines; National Renewable Energy Laboratory (NREL): Golden, CO, USA, 2005; Chapter 7.1; pp. 165-174.

12. Lin, C.-Y.; Lin, H.-A. Engine performance and emission characteristics of a three-phase emulsion of biodiesel produced by peroxidation. Fuel Process. Technol. 2007, 88, 35-41. [CrossRef]

13. Yoshimoto, Y.; Tamaki, H. Reduction of $\mathrm{NO}_{\mathrm{x}}$ and smoke emissions in a diesel engine fueled by biodiesel emulsion combined with EGR. In SAE Transactions; SAE International: Warrendale, PA, USA, 2001; pp. $467-475$.

14. Ogunkoya, D.; Li, S.; Rojas, O.J.; Fang, T. Performance, combustion, and emissions in a diesel engine operated with fuel-in-water emulsions based on lignin. Appl. Energy 2015, 154, 851-861. [CrossRef]

15. Nadeem, M.; Rangkuti, C.; Anuar, K.; Haq, M.; Tan, I.; Shah, S. Diesel engine performance and emission evaluation using emulsified fuels stabilized by conventional and gemini surfactants. Fuel 2006, 85, 2111-2119. [CrossRef]

16. Basha, S.A.; Anand, R. Role of nanoadditive blended biodiesel emulsion fuel on the working characteristics of a diesel engine. J. Renew. Sustain. Energy 2011, 3, 023106. [CrossRef]

17. Ithnin, A.M.; Yahya, W.J.; Ahmad, M.A.; Ramlan, N.A.; Kadir, H.A.; Sidik, N.A.C.; Koga, T. Emulsifier-free water-in-diesel emulsion fuel: Its stability behaviour, engine performance and exhaust emission. Fuel 2018, 215, 454-462. [CrossRef]

18. Fahd, M.E.A.; Wenming, Y.; Lee, P.S.; Chou, S.K.; Yap, C.R. Experimental investigation of the performance and emission characteristics of direct injection diesel engine by water emulsion diesel under varying engine load condition. Appl. Energy 2013, 102, 1042-1049. [CrossRef]

19. Abu-Zaid, M. Performance of single cylinder, direct injection diesel engine using water fuel emulsions. Energy Convers. Manag. 2004, 45, 697-705. [CrossRef]

20. Scragg, A.H.; Morrison, J.; Shales, S.W. The use of a fuel containing Chlorella vulgaris in a diesel engine. Enzym. Microb. Technol. 2003, 33, 884-889. [CrossRef]

21. Fayyad, S.M.; Abu-Ein, S.; Al-Marahleh, G.; Al-Momani, W.; Al-Momani, M.; Abulghanam, Z.; Badran, O.; Abu-Rahmah, T. Experimental emulsified diesel and benzen investigation. Res. J. Appl. Sci. Eng. 2010, 2, 268-273.

22. Davis, J.; Johnson, D.; Edgar, D.; Wardlow, G.; Sadaka, S. $\mathrm{NO}_{\mathrm{x}}$ emissions and performance of a single-cylinder diesel engine with emulsified and non-emulsified fuels. Appl. Eng. Agric. 2012, 28, 179-186. [CrossRef]

23. Grimes, P.; Hagstrand, W.; Psaila, A.; Seth, J.; Waldron, J. Emulsified Biodiesel Fuel Effects on Regulated Emissions; Diesel Net Technical Report 2011; Alternative Petroleum Technologies: Reno, NV, USA, 2018; Available online: http://www.dieselnet.com/papers/1112grimes.pdf.

24. Dantas Neto, A.; Fernandes, M.; Neto, E.B.; Dantas, T.C.; Moura, M. Alternative fuels composed by blends of nonionic surfactant with diesel and water: Engine performance and emissions. Braz. J. Chem. Eng. 2011, 28, 521-531. [CrossRef] 
25. Yoshimoto, Y.; Onodera, M.; Tamaki, H. Performance of a diesel engine using transesterified fuel from vegetable oil (effects of water emulsification). Trans. Jpn. Soc. Mech. Eng. Ser. B 2001, 5, 67-653.

26. Koc, A.B.; Abdullah, M. Performance and $\mathrm{NO}_{x}$ emissions of a diesel engine fueled with biodiesel-diesel-water nanoemulsions. Fuel Process. Technol. 2013, 109, 70-77. [CrossRef]

27. Elsanusi, O.A.; Roy, M.M.; Sidhu, M.S. Experimental investigation on a diesel engine fueled by diesel-biodiesel blends and their emulsions at various engine operating conditions. Appl. Energy 2017, 203, 582-593. [CrossRef]

28. Uludamar, E.; Yıldızhan, Ş.; Aydın, K.; Özcanlı, M. Vibration, noise and exhaust emissions analyses of an unmodified compression ignition engine fuelled with low sulphur diesel and biodiesel blends with hydrogen addition. Int. J. Hydrog. Energy 2016, 41, 11481-11490. [CrossRef]

29. Taghizadeh-Alisaraei, A.; Ghobadian, B.; Tavakoli-Hashin, T.; Mohtasebi, S.S. Vibration analysis of a diesel engine using biodiesel and petrodiesel fuel blends. Fuel 2012, 102, 414-422. [CrossRef]

30. Al-lwayzy, S.; Yusaf, T.; Al-Juboori, R. Biofuels from the fresh water microalgae Chlorella vulgaris (FWM-CV) for diesel engines. Energies 2014, 7, 1829-1851. [CrossRef]

31. Ozsezen, A.N.; Canakci, M.; Turkcan, A.; Sayin, C. Performance and combustion characteristics of a DI diesel engine fueled with waste palm oil and canola oil methyl esters. Fuel 2009, 88, 629-636. [CrossRef]

32. An, H.; Yang, W.M.; Chou, S.K.; Chua, K.J. Combustion and emissions characteristics of diesel engine fueled by biodiesel at partial load conditions. Appl. Energy 2012, 99, 363-371. [CrossRef]

33. Canakci, M.; Ozsezen, A.N.; Turkcan, A. Combustion analysis of preheated crude sunflower oil in an IDI diesel engine. Biomass Bioenergy 2009, 33, 760-767. [CrossRef]

34. Qi, D.H.; Chen, H.; Geng, L.M.; Bian, Y.Z.; Ren, X.C. Performance and combustion characteristics of biodiesel-diesel-methanol blend fuelled engine. Appl. Energy 2010, 87, 1679-1686. [CrossRef]

35. Prasath, B.R.; Porai, P.; Shabir, M.F. An experimental comparison of combustion, performance and emission in a single cylinder thermal barrier coated diesel engine using diesel and biodiesel. Glob. J. Sci. Front. Res. 2010, 10, 2-8.

36. Buyukkaya, E. Effects of biodiesel on a DI diesel engine performance, emission and combustion characteristics. Fuel 2010, 89, 3099-3105. [CrossRef]

37. Ozsezen, A.N.; Canakci, M.; Sayin, C. Effects of biodiesel from used frying palm oil on the performance, injection, and combustion characteristics of an indirect injection diesel engine. Energy Fuels 2008, 22, 1297-1305. [CrossRef]

38. Sanjid, A.; Kalam, M.A.; Masjuki, H.H.; Varman, M.; Zulkifli, N.W.B.M.; Abedin, M.J. Performance and emission of multi-cylinder diesel engine using biodiesel blends obtained from mixed inedible feedstocks. J. Clean. Product. 2016, 112, 4114-4122. [CrossRef]

39. Tesfa, B.; Mishra, R.; Gu, F.; Ball, A.D. Water injection effects on the performance and emission characteristics of a CI engine operating with biodiesel. Renew. Energy 2012, 37, 333-344. [CrossRef]

40. Ashok, M.P. Study of the performance and emissions of the compression-ignition (CI) engine using ethyl acetate as a surfactant in ethanol-based emulsified fuel. Energy Fuels 2010, 24, 1822-1828. [CrossRef]

41. Hasannuddin, A.K.; Yahya, W.J.; Sarah, S.; Ithnin, A.M.; Syahrullail, S.; Sugeng, D.A.; Razak, I.F.A.; Fatah, A.Y.A.; Aqma, W.S.; Rahman, A.H.A.; et al. Performance, emissions and carbon deposit characteristics of diesel engine operating on emulsion fuel. Energy 2018, 142, 496-506. [CrossRef]

42. Bidita, B.S.; Suraya, A.R.; Shazed, M.A.; Salleh, M.A.M.; Idris, A. Influence of fuel additive in the formulation and combustion characteristics of water-in-diesel nanoemulsion fuel. Energy Fuels 2014, 28, 4149-4161. [CrossRef]

(C) 2019 by the authors. Licensee MDPI, Basel, Switzerland. This article is an open access article distributed under the terms and conditions of the Creative Commons Attribution (CC BY) license (http://creativecommons.org/licenses/by/4.0/). 